\title{
The effect of fermentation period on physicochemical properties of Lactobacillus casei fermented sweet corn meal (Zea may saccharate Sturt)
}

\author{
${ }^{1}$ Anasiru, M.A., ${ }^{1}$ Ntau, L., ${ }^{2}$ Sumual, M.F., ${ }^{2}$ Assa, J. and ${ }^{1 *}$ Labatjo, R. \\ ${ }^{I}$ Department of Nutrition, Gorontalo Health Polytechnic, Gorontalo, Indonesia \\ ${ }^{2}$ Department of Post Graduate Program, Faculty of Food Science and Technology, Sam Ratulangi \\ University, Manado, Indonesia
}

\begin{abstract}
Article history:
Received: 3 September 2018

Received in revised form: 30

September 2018

Accepted: 7 October 2018

Available Online: 18 October 2018
\end{abstract}

\section{Keywords:}

Sweet corn,

Meal,

Physicochemical Properties,

Fermentation,

Lactobacillus casei

\begin{abstract}
The purpose of this research was to study the effect of fermentation on the chemical properties of fermented sweet corn meal using Lactobacillus casei. Complete Randomized Design (CRD) was used in this research. Sweet corn meal was fermented with $L$. casei at different fermentation periods, i.e. 24, 48 and $72 \mathrm{hrs}$. Physicochemical analysis such as moisture content, starch content, amylose content, size of starch granules, crude fibre content and total reducing sugar content was performed. The results showed that the 24hour fermented sweet corn meal had the lowest water content $(5.15 \%)$ of all the various fermentation period. The 48-hour fermented sweet corn meal had the lowest amylose content $(0.43 \%)$ and the lowest crude fiber content $(2.32 \%)$. Fermented flour would make a significant improvement to the quality of the flour and its products such as bread.
\end{abstract}

DOI:

https://doi.org/10.26656/fr.2017.3(1).225

\section{Introduction}

Corn (Zea mays L) are grain crops, and seasonal crops with a life cycle of 80-150 days. In Indonesia, Gorontalo is the province with the best corn commodity and, it is the largest exporter to countries namely Malaysia, Philippines and South Korea. Approximately 91,500 tonnes of corn is produced per year from Gorontalo. In 2014, corn production was 719,787 tonnes with dried corn kernels production increased 7.58\% compared in 2013. However, in 2015, corn production reduced to 643, 512 tonnes. (Gorontalo Central Bureau of Statistics, 2015).

Sweet corn (Zea mays saccharate Strut) is one of the agricultural commodities favoured by Gorontalo farmers due to shorter harvest age of 70 days compared to the usual corn. Processed into flour (Irawan et al., 2017), sweet corn flour has great characteristics that greatly affects the quality of food products. It can be fermented to obtain the desired flour (Aini et al., 2016) with significant physicochemical properties and functional characteristics of cornstarch, enzymatically. Fermented sweet corn flour was reported to have a finer texture than the original corn flour and, it has different gelatinizing properties. The addition of microbes such as lactic acid bacteria during the fermentation process can improve the quality of flour and bread development in bread production (Gerez et al., 2006). In addition, different fermentation period also produces different physicochemical properties which will be investigated in the study. The objective of this research is to evaluate the physicochemical properties of different fermented periods of sweet corn flour using L. casei.

\section{Materials and methods}

The processing of fermented sweet corn flour was conducted in the laboratory of Livestock Production Technique Faculty of Livestock, Sam Ratulangi University of Manado from March to April 2018. Physicochemical analysis of fermented sweet corn flour is conducted at Integrated Laboratory of Sam Ratulangi University of Manado.

\subsection{Fermented sweet corn meal production}

The production of fermented sweet corn meal is shown in Figure 1. Sweet corn, harvested at the $90^{\text {th }}$ day, was dried in the oven for $48 \mathrm{hrs}$ at $60^{\circ} \mathrm{C}$ until the water content reached $\pm 17 \%$. Then, the sweet corn kernels were separated from the cobs. The sweet corn kernels were weighed and milled using a corn grain mill to produce sweet corn meal. Sweet corn meal was added with $L$. casei at a ratio of $3 \mathrm{~g} / \mathrm{kg}$ of sweet corn meal. Aquadest and coconut water were added next at a ratio of 


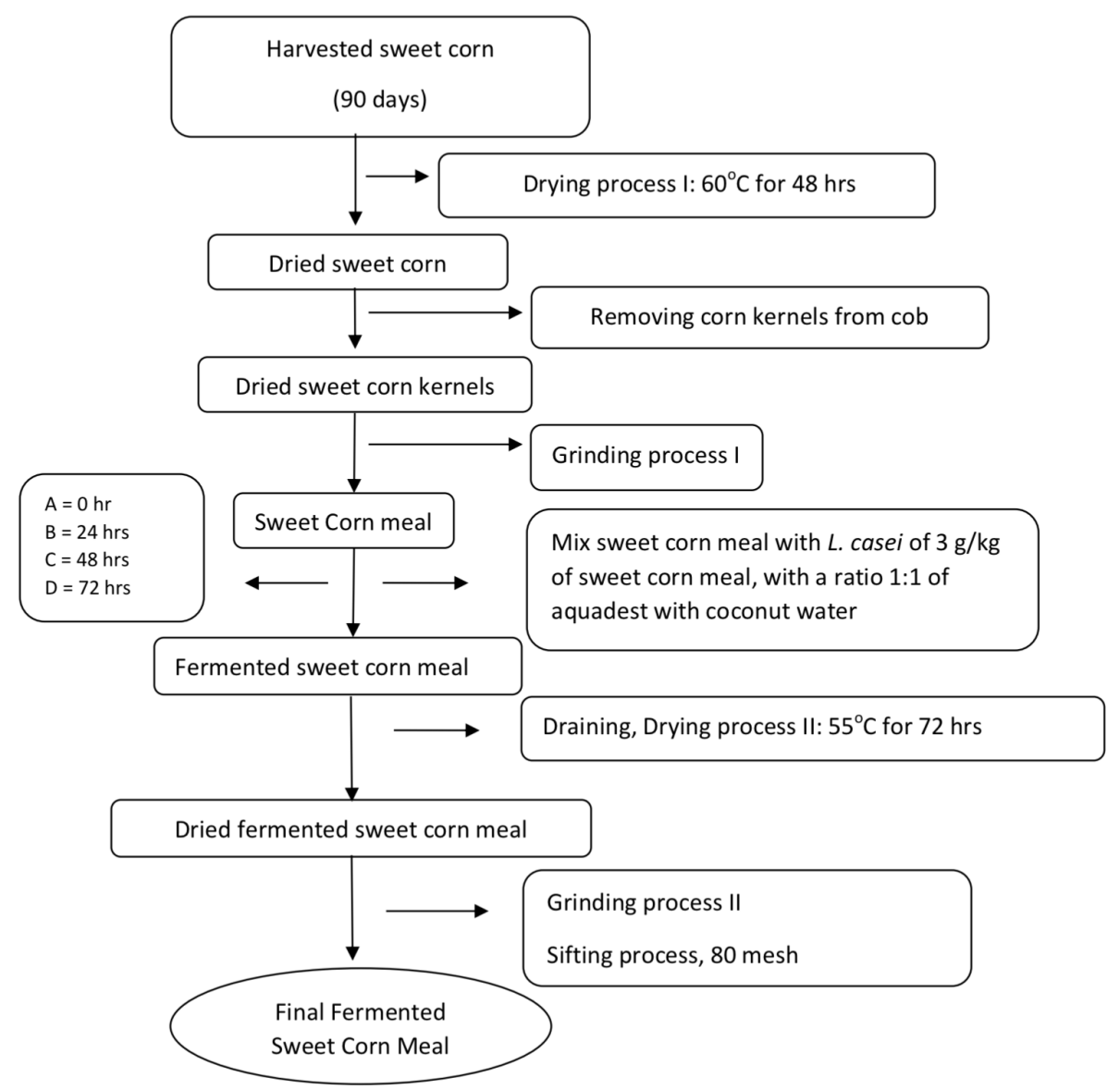

Figure 1. Production of fermented sweet corn meal

1:1 and mixed well. The mixture was separated into three (3) different containers equally and ferment accordingly; 24, 48 and 72 hrs. For control, non-fermented sweet corn meal was used. After the fermentation, the sweet corn meal was re-dried at $55^{\circ} \mathrm{C}$ for $72 \mathrm{hrs}$. The dried fermented sweet corn meal was ground and sieved through an 80-mesh sieve to produce a finer flour. The final weight of the fermented sweet corn meal was recorded to calculate the yield.

\subsection{Completely Randomized Design (CRD)}

The experimental design used was the Completely Randomized Design (CRD). There were four treatments and each treatment with three replicates. The treatments carried out as follows:

$\mathrm{A}=$ Sweet corn meal with no addition of $L$. case $i$ and no fermentation.

$\mathrm{B}=$ Sweet corn meal fermented for $24 \mathrm{hrs}$

$\mathrm{C}=$ Sweet corn meal fermented for $48 \mathrm{hrs}$

$\mathrm{D}=$ Sweet corn meal fermented for $72 \mathrm{hrs}$

\subsection{Physicochemical analysis}

\subsubsection{Moisture content}

The moisture content analysis was conducted using the oven-drying method (AOAC, 1995). A total of $3 \mathrm{~g}$ of fermented sweet corn meal was weighed into a cup and placed into the oven with a temperature of $100^{\circ} \mathrm{C}$ to be dried until a constant weight was obtained (approximately $6 \mathrm{hrs}$ or more). The moisture content was calculated using Equation (1):

moisture content $(\%)=\frac{\text { (initial weight }(\mathrm{g})-\text { final weight }(\mathrm{g}))}{\text { initial weight }(\mathrm{g})} \times 100 \%$

\subsubsection{Starch content}

Fermented sweet corn meal was weighed 2 to $5 \mathrm{~g}$ in a $250 \mathrm{~mL}$ glass beaker and added with $50 \mathrm{~mL}$ of distilled water. The mixture was stirred for an hour and then filtered and washed with distilled water to a filtrate volume of $250 \mathrm{~mL}$. This filtrate may contain dissolved carbohydrate that was removed. For materials containing fat, the residue on the filter paper was washed five (5) times with $10 \mathrm{~mL}$ of ether. The ether was evaporated from the residue and then washed with $150 \mathrm{~mL}$ of $10 \%$ alcohol to dissolve the carbohydrates. The residue from the filter paper was transferred quantitatively into a 200 $\mathrm{mL}$ Erlenmeyer flask by washing with distilled water and then added with $20 \mathrm{~mL}$ of $\mathrm{HCl} \pm 25 \%$ (specific gravity 1.125). The Erlenmeyer flask was covered with cooling back and heated in a boiling water bath for $2.5 \mathrm{hrs}$. It is left to cool and subsequently neutralized with $45 \%$ $\mathrm{NaOH}$ solution, diluted to a volume of $500 \mathrm{ml}$, then strained. The glucose obtained from the filtrate was expressed as the sugar content and multiplied by 0.9 to calculate the weight of the starch. 


\subsection{Amylose content}

The amylose content was determined following the IRRI method (AOAC, 1995).

\subsubsection{Standard curve}

Pure amylose was weighed $40 \mathrm{mg}$ into a test tube and added with $1 \mathrm{~mL}$ of $95 \%$ ethanol and $9 \mathrm{~mL}$ of $1 \mathrm{~N}$ $\mathrm{NaOH}$. The mixture was boiled for 10 mins until the gel forms. The formed gel was transferred to a $100 \mathrm{~mL}$ measuring flask and topped up with distilled water. The solution was pipetted $1 \mathrm{~mL}, 2 \mathrm{~mL}, 3 \mathrm{~mL}, 4 \mathrm{~mL}$ and $5 \mathrm{~mL}$ into five different $100 \mathrm{~mL}$ measuring flask. Each of the measuring flask was added with $0.1 \mathrm{~N}$ acetic with the following volume $0.2 \mathrm{~mL}, 0.4 \mathrm{~mL}, 0.6 \mathrm{~mL}, 0.8 \mathrm{~mL}$ and 1 $\mathrm{mL}$ to $1 \mathrm{~mL}, 2 \mathrm{~mL}, 3 \mathrm{~mL}, 4 \mathrm{~mL}$ and $5 \mathrm{~mL}$ respectively. Then, $2 \mathrm{~mL}$ of iodine solution was added into the measuring flask. The intensity of the blue colour formed was measured using a spectrophotometer at a wavelength of $625 \mathrm{~nm}$. The graph of the concentration against absorbance was plotted.

\subsubsection{Preparation of sample}

Fermented sweet corn meal was weighed $100 \mathrm{mg}$ and added with $1 \mathrm{ml}$ of $95 \%$ ethanol and $9 \mathrm{~mL}$ of $1 \mathrm{~N}$ $\mathrm{NaOH}$. The mixture was boiled for 10 mins until the gel forms. The formed gel was transferred to a $100 \mathrm{~mL}$ measuring flask and topped up with distilled water. The solution was pipetted $5 \mathrm{~mL}$ into a $100 \mathrm{~mL}$ measuring flask and added with $1 \mathrm{~mL} 0.1 \mathrm{~N}$ acetic Then, $2 \mathrm{~mL}$ of iodine solution was added into the measuring flask. The intensity of the blue colour formed was measured using a spectrophotometer at a wavelength of $625 \mathrm{~nm}$. The amylose content was determined from the plotted graph of concentration against absorbance.

\subsection{Starch granules}

The forms of starch granules were viewed using a Scanning Electron Microscope (SEM). The sample was weighed $5 \mathrm{~g}$ and added with distilled water in the ratio 1 : 4. The solution was heated in a water bath and stirred until the specific temperature following: $64^{\circ} \mathrm{C}$ for sample A, $59^{\circ} \mathrm{C}$ for sample $\mathrm{B}, 65^{\circ} \mathrm{C}$ for sample $\mathrm{C}$, and $64^{\circ} \mathrm{C}$ for sample D. The gelatinized structures were observed with SEM at a magnification 2000 times.

\subsection{Crude fiber}

Crude fiber content was determined following procedures of Apriyantono et al. (1989). A total of $2 \mathrm{~g}$ of fermented sweet corn meal was weighed and extracted with petroleum ether solvent using Soxhlet. The fat-free sample was transferred quantitatively into a $600 \mathrm{~mL}$ Erlenmeyer flask and added with $200 \mathrm{~mL}$ of boiling $\mathrm{H}_{2} \mathrm{SO}_{4}$. The Erlenmeyer flask was then placed into the cooling back in a closed condition and heated to boiling for $30 \mathrm{mins}$ and occasionally shaken. Once completed, the solution was filtered, and the residues were washed with boiling water. The washing was considered done when the filtrate was tested with litmus paper as not acidic. The residue was transferred into another Erlenmeyer flask and washed using $200 \mathrm{~mL}$ of boiled $\mathrm{NaOH}$ to completely ensure all residue from the filter paper was transferred. The solution was boiled again for 30 mins with the cooling back, occasionally shaken. Once the boiling process completed, the solution was filtered and washed with $10 \% \mathrm{~K}_{2} \mathrm{SO}_{4}$ and then with boiling water followed with $95 \%$ alcohol. The filter paper was dried in an oven at $105^{\circ} \mathrm{C}$ to a constant weight (approximately 1-2 hrs) and weighed after being cooled in a desiccator. The crude fiber content calculated using Equation (2):

Crude fiber content $(\%)=\frac{\mathrm{W}_{2}-\mathrm{W}_{1}}{\mathrm{~W}} \times 100 \%$

Where $\mathrm{W}=$ weight of the sample analyzed $(\mathrm{g})$; $\mathrm{W} 1=$ weight of filter paper $(\mathrm{g})$; and $\mathrm{W} 2$ = weight of residue and dried filter paper $(\mathrm{g})$.

\subsection{Total reducing sugar content}

The reduction sugar analysis aimed to determine the amount of reducing sugar contained in fermented sweet corn meal following the procedures of Luff-Schoorl (Sudarmaji et al., 1997)

\subsubsection{Sample preparation}

Fermented sweet corn flour was weighed $5 \mathrm{~g}$ into a $250 \mathrm{~mL}$ measuring flask and topped up with distilled water. The mixture was mixed well and filtered into a new $250 \mathrm{~mL}$ measuring flask. While shaking the solution, $10 \mathrm{~mL}$ of half wet $\mathrm{Pb}$ acetate solution was added. The adequacy of $\mathrm{Pb}$ acetate solution added was tested by dripping $10 \% \quad \mathrm{Na}_{2} \mathrm{HPO}_{4}$. The white precipitation from the reaction indicated sufficient addition of $\mathrm{Pb}$ acetate solution. About $15 \mathrm{~mL}$ of $10 \%$ $\mathrm{Na}_{2} \mathrm{HPO}_{4}$ to precipitate excess $\mathrm{Pb}$ acetate until no precipitation. The solution was topped up with distilled water, mixed well and left to stand for 30 mins. The solution was then filtered.

\subsubsection{Determination of sugar content before inversion}

The filtrate was pipetted $10 \mathrm{~mL}$ into a $500 \mathrm{~mL}$ Erlenmeyer flask and added with $15 \mathrm{~mL}$ of distilled water, boiling stones and $25 \mathrm{~mL}$ of Luff-Schoorl solution. The mixture was heated for 2 mins until boiling and simmered for 10 mins in a water bath. Immediately, the flask was removed and cooled in ice bath. After cooling, $10-15 \mathrm{ml}$ of $30 \%$ KI solution and $25 \mathrm{ml}$ of $25 \%$ 
$\mathrm{H}_{2} \mathrm{SO}_{4}$ was added. It was titrated immediately with $0.1 \mathrm{~N}$ $\mathrm{Na}_{2} \mathrm{~S}_{2} \mathrm{O}_{3}$ solution and $0.5 \%$ starch solution as an indicator. Blank sample was prepared by replacing the sample with distilled water following the similar procedure. The volume of $\mathrm{Na}_{2} \mathrm{~S}_{2} \mathrm{O}_{3}$ solution used to titrate sample subtracted from the volume used to titrate blank sample determines the sugar content before inversion obtained from the Luff-Schoorl table. The sugar content before inversion (\%) was calculated using Equation (3):

$\%=\frac{\mathrm{mg} \times \mathrm{FP} \times 100 \%}{\text { sample }(\mathrm{mg})}$

\subsubsection{Determination of sugar content after inversion}

The filtrate was pipetted $50 \mathrm{~mL}$ into a $100 \mathrm{~mL}$ measuring flask and added with $5 \mathrm{~mL}$ of $25 \% \mathrm{HCl}$. The measuring flask was inserted into the water bath heated to $60-70^{\circ} \mathrm{C}$ and allowed to stand for 10 mins (to invert sugar). The measuring flask was then cooled and added with $30 \% \mathrm{NaOH}$ until $\mathrm{pH}$ reached 7 and topped up with distilled water. The mixture was pipetted $10 \mathrm{~mL}$ and added with $15 \mathrm{~mL}$ of distilled water, boiling stones and $25 \mathrm{~mL}$ of Luff-Schoorl solution in a $500 \mathrm{~mL}$ Erlenmeyer flask with cover. The flask was heated about 2 mins to boil and continue to boil in the water bath for 10 mins. The flask was removed and cooled immediately with ice and added with $10-15 \mathrm{~mL}$ of $30 \% \mathrm{KI}$ solution and $25 \mathrm{~mL}$ of $25 \% \mathrm{H}_{2} \mathrm{SO}_{4}$ solution. It was titrated immediately with $0.1 \mathrm{~N} \mathrm{Na} \mathrm{Na}_{2} \mathrm{~S}_{2} \mathrm{O}_{3}$ solution and $0.5 \%$ starch solution as an indicator. Blank sample was prepared by replacing the sample with distilled water following the similar procedure.

The sugar levels were calculated using Equations (4) and (5):

Sucrose level $=(\%$ sugar after inversion of sugar before inversion) x 0.95

Sugar levels were calculated $=\%$ sugar after inverse $\mathrm{x} 0.95$.

\subsection{Data analysis}

Data of research results were analysed with analysis of variance (ANOVA) and Least Significance Different (LSD) test to determine significant difference.

\section{Results and discussion}

\subsection{Physicochemical properties of fermented sweet corn} meal

The results of this research are presented in Table 1.

\subsection{Moisture content}

From Table 1, the moisture content of the fermented sweet corn meal $(p<0.05)$ varied for the different fermentation time. The moisture content of the fermented sweet corn meal ranged from 5.15-6.91\%. The 24-hour fermented sweet corn meal had the lowest moisture content $(5.15 \%)$, followed by 48 -hour fermented sweet corn meal (5.86\%) and the 72-hour fermented sweet corn meal has the highest moisture content $(6.91 \%)$. On the other hand, the non-fermented sweet corn meal recorded $8.08 \%$ of moisture content. The 24 -hour fermented sweet corn meal and 48-hour fermented sweet corn meal were significantly different $(p<0.05)$ from the 72-hour fermented sweet corn meal and non-fermented sweet corn meal. This could be due to the drying process of unfermented sweet corn meal which was performed for $48 \mathrm{hrs}$ compared to fermented sweet corn meal, which was performed longer. Drying time affects the moisture content, this is because long drying causes the amount of water that is evaporated more so that the water content in the flour is reduced (Lubis, 2008).

The low moisture content of food products also indicates a better stability and longer shelf life. In addition, water is required by bacteria, fungi and yeast to multiply so that there will be changes in food during the early stages of fermentation. Water is also needed for ongoing biochemical reactions that occur in food, such as enzyme-catalyst reactions (Winarno, 2004). Therefore, the 24-hour fermented with the lowest moisture content has a longer shelf life.

The requirement of moisture content of a quality flour based on SNI 01-3727-1995 is maximum 10\%. It

Table 1. Average results of physicochemical properties of fermented sweet corn meal

\begin{tabular}{|c|c|c|c|c|c|}
\hline \multirow{2}{*}{ Observation parameter } & \multicolumn{4}{|c|}{ Treatment } & \multirow{2}{*}{$5 \%$ LSD } \\
\hline & A & B & $\mathrm{C}$ & $\mathrm{D}$ & \\
\hline Moisture content (\%) & $8.08^{\mathrm{b}}$ & $5.15^{\mathrm{a}}$ & $5.86^{\mathrm{a}}$ & $6.91^{\mathrm{b}}$ & 1.22 \\
\hline Starch content (\%) & $2.09^{\mathrm{a}}$ & $1.14^{\mathrm{a}}$ & $2.04^{\mathrm{a}}$ & $0.94^{\mathrm{a}}$ & - \\
\hline Amylose content (\%) & $0.82^{\mathrm{bc}}$ & $0.62^{\mathrm{ab}}$ & $0.43^{\mathrm{a}}$ & $0.88^{\mathrm{cd}}$ & 0.21 \\
\hline Crude fiber content (\%) & $3.97^{\mathrm{c}}$ & $3.65^{\mathrm{b}}$ & $2.32^{\mathrm{a}}$ & $3.93^{\mathrm{c}}$ & 0.26 \\
\hline Total reducing sugar (\%) & $28.50^{\mathrm{b}}$ & $19.00^{\mathrm{a}}$ & $19.00^{\mathrm{a}}$ & $22.40^{\mathrm{a}}$ & 4.75 \\
\hline
\end{tabular}

$\mathrm{A}=$ non-fermented sweet corn meal; $\mathrm{B}=24$-hour fermented sweet corn meal; $\mathrm{C}=48$-hour fermented sweet corn meal; and $\mathrm{D}=$ 72-hour fermented sweet corn meal. Values with different alphabet superscript are significantly different $(p<0.05)$ 
can be concluded that the moisture content of the fermented sweet corn flour satisfied the requirements of a quality flour based on SNI 01-3727-1995.

\subsection{Starch content}

There was no significant difference $(\mathrm{p}>0.05)$ in the starch content, expressed in percentage, of the fermented sweet corn meals. Non-fermented sweet corn meal had $2.09 \%$ of starch content. The 72-hour fermented sweet corn meal recorded the lowest starch content of $0.94 \%$ while the 48-hour fermented sweet corn meal produced the highest starch content of $2.04 \%$. The 24-hour fermented sweet corn meal contained $1.14 \%$ of starch content.

Fermented corn flour produces a relatively low starch content compared to corn flour without fermentation. The starch content in corn flour is $68.20 \%$ (Juniwati, 2003) while sweet corn flour had $64.09 \%$ of starch content (Irawan et al., 2017). Herawati and Widowati (2009) revealed that the high content of starch in foodstuffs is influenced by plants, soil fertility, climate, and storage time.

The allegedly low starch content in fermented sweet corn meal was affected by the length of storage and the presence of bacteria. To further preserve the starch content, the sweet corn meal that has passed through the process of milling stage $I$ is not immediately done fermentation process.

Starch is a type of polysaccharide widely used in food processing. The starch polymer consists of amylose and amylopectin, although both are made up of the same molecule of glucopyranose, the characteristics of the two polymers are different. The function of starch in the food is to form a unique texture, flavour, and aroma, in the use of some types of starch can be modified to produce food products according to the desired product by considering the characteristics and content of both starch polymers (Harijono et al., 2016). However, foods with high starch content easily absorb water due to the presence of reactive amylopectin (Herawati and Widowati, 2009)

\subsection{Amylose content}

The amylose content of each fermented sweet corn meal at different fermentation period was significantly different $(p<0.05)$. The amylose content for 24-hour, 48hour, and 72-hour fermented sweet corn meal were $0.62 \%, 0.43 \%$ and $0.88 \%$ respectively. The amylose content in non-fermented sweet corn meal was $0.82 \%$. A further test of BNT showed significant difference ( $\mathrm{p}$ $<0.05$ ) in each treatment of fermented corn flour.

\subsection{Starch granules}

Figure 2 illustrates the starch granules of nonfermented sweet corn meal, 24-hour fermented sweet corn meal, 48-hour fermented sweet corn meal, and 72hour fermented sweet corn meal viewed under SEM.
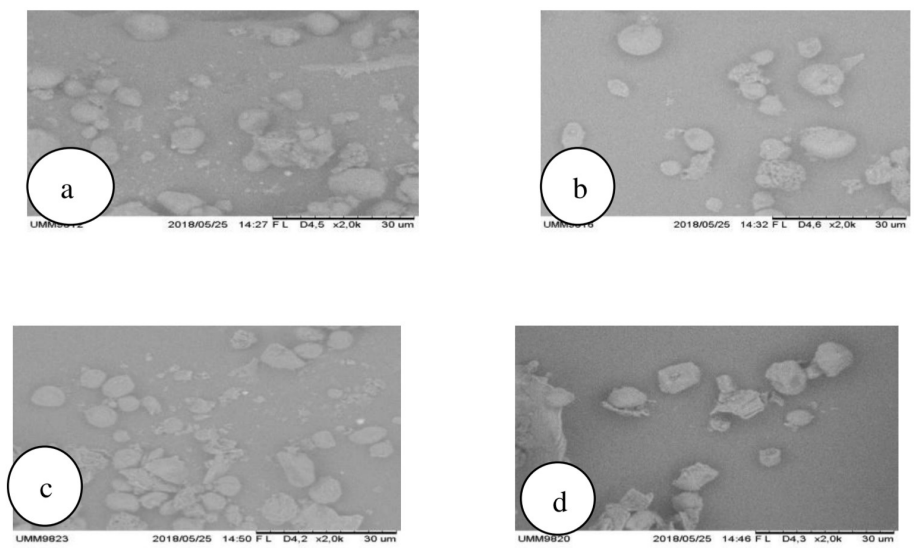

Figure 2. Starch granules. a: non-fermented sweet corn meal; b: 24-hour fermented sweet corn meal; c: 48-hour fermented sweet corn meal; and d: 72-hour fermented sweet corn meal.

It was observed from Figure 2 that the starch granules had no difference. This is due to the sweet corn starch granules for each treatment produced non-flat rounded granules during the gelatinization process. Nonflat rounded granules indicate that amylose could have been released.

\subsection{Crude fiber}

The crude fiber content of the fermented sweet corn meal was expressed in percentage. The results in Table 1 showed significant difference $(p<0.05)$ for each treatment of the sweet corn meal. The 72-hour fermented sweet corn meal had the highest crude fiber content of $3.93 \%$ compared to 24-hour and 48-hour fermented sweet corn meal.

The result of crude fiber obtained in the fermented corn flour did not meet the requirements specified in SNI for corn flour, which is the maximum of $1.5 \%$. In this study, the lowest crude fiber was $2.32 \%$ which was from the 48-hour fermented sweet corn meal.

Fiber is an integral part of the plant's natural structure composed of several components such as lignin, cellulose, hemicellulose and pectic substances, gums, waxes and undigested oligosaccharides, hemicellulose and pectic substances capable of binding water and inflate are called soluble fibers. Corn fiber consists of $70 \%$ hemicellulose and $23 \%$ cellulose and $0.1 \%$ lignin (Boyer, 2003). The high-fiber corn portion is found on the skin (pericarp) and tip cap (Watson, 2003). In the processing of sweet corn flour, allegedly part of the skin was carried on the grinding process, causing the different fiber content in each treatment. Irawan et al. (2017) reported that the fiber content of sweet corn 
starch ranged from 11.27 to $23.71 \%$. However, the crude fiber content in the fermented sweet corn flour (2.32$3.97 \%$ ) may be due to the fermentation process of the sweet corn meal as the skin part dissolves in the fermentation process.

\subsection{Sugar}

The total sugar on the fermented sweet corn flour was significantly different $(\mathrm{p}<0.05)$ from non-fermented sweet corn meal. The 24-hour and 48-hour fermented sweet corn meal had $19.00 \%$ total sugar content while the 72-hour fermented sweet corn had $22.40 \%$ total sugar content. Non-fermented sweet corn meal had the highest total sugar content of $28.50 \%$.

The increase of the total sugar content when the sweet corn meal was fermented for $72 \mathrm{hrs}$ could be due to the $L$. casei ability to degrade the cell wall of maize into simple sugars and amino acids during fermentation (Aini et al., 2016).

\section{Conclusion}

Fermented sweet corn meal with $L$. casei had slightly different physicochemical properties compared to non-fermented sweet corn meal. Fermented sweet corn meal had lower moisture content, starch content, crude fiber and total sugar content compared to nonfermented sweet corn meal. The starch granules of both fermented and non-fermented sweet corn meal were similar. Overall, 48-hour fermented sweet corn meal produced the best quality flour for bread production.

\section{Conflict of Interest}

The authors declared no conflict of interest.

\section{Acknowledgments}

The authors would like to acknowledge the technical support provided by Sam Ratulangi University and Gorontalo Health Polytechnic.

\section{References}

Aini, N., Gunawan, W. and Budi, S. (2016). Physical, Chemical and Functional Properties of Corn Flour Processed by Fermentation. Agritech, 36(2), 160-168 [In Bahasa Indonesia]. https://doi.org/10.22146/ agritech. 12860

AOAC. (1995). Official Methods of Analysis, $16^{\text {th }} \mathrm{ed}$. Gaithersburg, Maryland: USA: AOAC International.

Apriyantono, D.F.A. (1989). Food Analysis Laboratory Instructions. Bogor: Ministry of Education and Culture, Directorate General of Higher Education,
Inter-University Center for Food and Nutrition Institute of Agriculture Bogor.

Boyer, C.D. and Shannon, J.C. (2003). Carbohydrates of the Kernel. In White, P.J. dan Johnson, L.A. (Eds). Corn: Chemistry and Technology, $2^{\text {nd }}$ ed. St. Paul, Minnesota, USA: American Association of Cereal Chemistry Inc.,

Gerez, L.C., Rollan, G.C. and Font de Valdez, G. (2006). Gluten breakdown by Lactobacilli andpediococci strains isolated from sourdough. Letters in Applied Microbiology, 42(5), 459-464. https:// doi.org/10.1111/j.1472-765X.2006.01889.x

Gorontalo Central Bureau of Statistics. (2015). Gorontalo dalam angka 2015. Retrieved on September 15, 2017 from website: https:// gorontalo.bps.go.id.

Harijono., Teti, E., Elok, W. and Kiki, F. (2016). Chemical dan Physical of Food. Jakarta: Bumi Aksara

Herawati, H. and Widowati, S. (2009). Characteristics of pearl rice made from sweet potato (Ipomea batatas). Buletin Teknologi Pascapanen Pertanian, 5, 37-44 [In Bahasa Indonesia].

Irawan, F. Sumual, M.F. and Pontoh, J. (2017). Effect of the age at harvest on physical characteristics of sweet corn flour (Zea mays saccharata Sturt). Jurnal Teknologi Pertanian, 8(1), 36-46 [In Bahasa Indonesia].

Watson S.A. (2003). Description, development, structure, and composition of the corn kernel. In White, P.J. dan Johnson, L.A. (Eds). Corn: Chemistry and Technology, $2^{\text {nd }}$ ed. St. Paul, Minnesota, USA: American Association of Cereal Chemistry Inc.

Winarno, F.G. (2004). Kimia Pangan dan Gizi. Jakarta: PT Gramedia Pustaka Utama. 